Горана Раичевић

Филозофски факултет

Универзитета у Новом Саду
УДК: 82:1 Andrić, I.

82:1 Auster, P.

Оригинални научни рад

\title{
ИСКЛИЗНУЋЕ ИЗ СТВАРНОСТИ: ИДЕНТИТЕТ КОД ИВЕ АНДРИЋА И ПОЛА ОСТЕРА*
}

Рад се бави паралелама између поетичких али и антрополошких и филозофских идеја Иве Андрића (1892-1975) и америчког постмодернистичког писца Пола Остера (Paul Auster, 1947), са нагласком на питању идентитета чије се исходиште проналази у оспољавању субјекта, као и у везама које овај остварује са другим људима.

Кључне речи: Иво Андрић (1892-1975), Paul Auster (1947), идентитет, језик, стварност

Песници не краду идеје, нег̄o ӣредају, йако, кроз векове, да се не уг̄асе, букиииње човечансӣва. Миломи Црььанки

Док су у делу Милоша Црњанског многи савремени критичари препознали модерно, а чак и постмодерно осећање света, кад је реч о другом великом српском писцу 20. столећа Иви Андрићу, готово да и нема покушаја да се о његовом стваралаштву говори са аспекта који би пробио ону љуштуру „класичности” у коју је затворено. Томе је свакако допринела чињеница да се писац историјских романа о народима Балкана, приповедач и хроничар појединачних судбина његових житеља захваћених историјском стихијом, већ после раних збирки тзв. експресионистичке поетске прозе (Ex Ponto, 1919. и Немири, 1920) определио за реалистички књижевни поступак - дакле за потпуно уклањање сваке субјективности из слике света коју је нека приповетка или роман требало да представи. Истина, Андрићево сликање реалности незамисливо је без осветљавања унутарњег света његових јунака, што се, огледајући се увек у свету спољашњих догађаја, такође представља као реалија и као неодвојиви део приче. Приповедање које претендује на истинитост, а које почива на реалности и аутентичности приповедача који причу саопштава (са фра Петром као идеалним наратором) свакако је Андрићеве критичаре намах одвраћало од сваког поређења са ауторима који су почињали да стварају када је његова стваралачка муза већ била на заласку

\footnotetext{
gorana.raicevic@gmail.com

Текст је настао у оквиру истраживања на пројекту Аспекти идентитета и њихово обликовање у српској књижевности (178005) који финансира Министарство за просвету и науку Републике Србије.
} 
или чак и деценијама након пишчевог физичког одласка са овог света. Андрић је тако могао да буде модеран и као следбеник Фројдове психоанализе, и као аутор код којег су неки критичари проналазили идеје егзистенцијализма или филозофије апсурда, али никако писац који је закорачио у еру постмодерности. Колико је овакво виђење српског нобеловца нетачно, покушаћу да аргументујем паралелама које је, и могуће и продуктивно упоставити између поетичких али и антрополошких и филозофских идеја Иве Андрића и америчког постмодернистичког писца јеврејског порекла Пола Остера (Paul Auster, 1947). ${ }^{1}$ Продуктивно у смислу да се Остерова мисао, односно његово дело, надовезује и надограђује на Андрићеву, тако да у њој можемо потражити одговоре које нам је наш писац ускратио.

О Андрићевој модерности, неправедно би било не поменути, сведоче свакако и модерни критички приступи: овај писац се, наиме, стицајем историјских околности нашао у жижи идеолошко-политичких преиспитивања балканског Гордијевог чвора након ратова 90-их, али је, такође се показало, постао један од „најзахвалнијих” аутора за истраживање са становишта тзв. имагологије, што полази од реалних али и мање-више искривљених представа једног људског колектива о другом. Босна као земља архетипске подељености заједница једног генетског супстрата, сукобљених по основу разлика које носе различити верски и културолошки обрасци, а која се непрестано, са својом трагичном историјом, налазила под лупом великог писца, открила се као погодно тле за проучавање историјских противречности и исходишта балканских сукоба, док је у исто време постало јасно да се Андрић у свом делу непрестано бавио питањима идентитета - индивидуалног и колективног. (Шта је то што чини осећање унутрашње заокружености сопства? Наслеђе, биолошки фактори, или уплив социјалних фактора које у животу реципирамо и који нас обликују? Може ли се уопште говорити о једнодущиносии људске јединке? Има ли континуитета те једнодущиностии појединца у времену? Ако нема, шта је то што покреће и обликује промену?...) Иако се можда чини да се ради о потпуно несамерљивим ауторима и поетикама, управо ће нам и Остерова усредсређеност на питања идентитета (иницирана свакако једним делом и његовим јеврејским пореклом, али и, супротно Андрићу, животом у анационалном агрегату америчког велеграда) указати на чињеницу да нека питања о човеку и његовом односу према свету и другим људима не застаревају, што, свакако, потврђује индиректно и познату тезу о универзалности језика литературе, која превазилази границе нација, култура и историјске епохе.

Несигурност властите издвоједности из света као тониокрегеровско проклетство уметника осуђеног на доживотну усамљеност и неразумевање

\footnotetext{
Остеров деда доселио се у Америку из Галиције, а у аутобиографском делу Invention of Solitude (код нас преведен као Оїкривање самоће - прев. Ивана Ђурић Пауновић) Остер каже да су два брата његовог деде, као аустроугарски војници, погинула у Првом светском рату. Ова чињеница говори о томе да су преци америчког писца и балкански нобеловац један део свог живота проживели у истој држави.
} 
тематизована је у Андрићевим младалачким писмима (Андрић, 2003), али је тек удружена са искуством мариборске тамнице (1914) отворила у писцу један специфичан мисаони и осећајни комплекс. Сазнање о опасности којој је изложен песник (и сваки човек) када се његова реч (али и говор уопште) тумачи у идеолошком и политичком кључу, као субверзивна по успостављени друштвени и државни поредак, свакако је младог писца наводило на то да узроке нестабилности и неизвесности човекове позиције у свету потражи како у стихијности историје, тако и у нестабилности комуникације појединца са Другим, са светом и људима које га окружују. Иако свестан тежине и величине напора да се изађе из себе и допре до Другога, када је стварност која нас окружује редовно на страни подела и непрестано ради у прилог одвајања и деоба, Андрић је својим делом показао да свака издвојеност из колектива сведочи о неизграђености личног идентитета, о немогућности успостављања колико-толико избалансираног односа појединца према свету и редовно је по тог појединца трагична или барем ускраћујућа. Корак ка другоме, корак је и према себи, сазнање другога отвара могућност разбијања окова задатости (позиције коју наслеђујемо рођењем или друштвеним статусом). Примери су бројни и разнолики у богатству нијанси и детаља.

Пример први: Већ јунак прве „објективно” писане Андрићеве приче (1920) - Алија Ђерзелез - славан, али и „несрећан” и „смијешан” ускраћен је јер не може да изађе из херојске матрице у коју га је колектив заробио. Он је епски јунак и аутентичан је све док не изађе из песме, паралелне стварности настале из архетипских наноса заједнице која га је уздигла на пиједестал изузетности. Сваки искорак у сферу приватног и љубавног дискурса чини од јунака карикатуру - човека неспособног да направи тај судбоносни корак из задатог оквира. Ђерзелез говори само једним језиком - језиком херојске парадигме: сишавши с коња, појављује се у паралелној стварности коју не разуме и и која не говори његовим језиком. Окидач његовог исклизнућа из реалног, али и отварач пукотине његове заокружености и целовитости јесте женска лепота - која у његовом свету не би ни смела да постоји, зато што је сваки херој по природи мизогин будући спреман на саможртвовање, док је жена прави носилац ероса. (Павловић, 2000). Зато Ђерзелез не познаје симболички језик мушко-женских односа, и то га незнање чини и смешним и трагичним актером света херојске усамљености на који је осуђен.

Као увијек кад би угледао женску љепоту, он изгуби у тили час сваки рачун о времену и истинским односима, и свако разумијевање за стварност која раставља људе једне од других... (Андрић, 2008: 22)

Надимао се од гнева. Не моћи до те влахиње; никад не моћи! И не моћи никог убити и ништа разбити! (Нови вал крви запљусну.) - Или да ово није варка! Да њега не магарче? Каква је ово шала опет? И какве су то жене до којих се не може као ни до Бога? А истог часа је јасно осјећао да су то претанки конци за његове руке и да - по који је то пут већ у животу!? - не може 
никако да схвати људе ни њихове најједноставније поступке, да ваља да се одрече и повуче, и да остаје сам са својим смијешним гњевом и сувишном снагом. (Андрић, 2008: 22)

Пример други: Ако Ђерзелез не уме да изгради мост до жене (а није случајно централни симбол Андрићев управо мост), за којом чезне и пати, Рајка Радаковић иде обрнутим путем, рушећи све ћуприје који су је са светом везивале. Постанак бића закључаног у своју страст, опсесију која би, по њеном слепом веровању, требало да је заштити од света и зацели ране очевог банкростства и пропасти, Андрић је приказао као постепено кидање свих Госпођичиних веза са људима: са мајком, слугама, просјацима, комшијама, са народом коме рођењем припада. Исклизнуће у паралелни свет, свет новца који постаје њена опсесија, одвија се постепено, али је неизбежно и деструктивно по ону која јој се препустила:

За њу одавно постоје два света, потпуно различна иако не потпуно одвојена. Једно је овај наш свет, оно што цео свет зове светом, целокупна шумна и непрегледна ова земља са људима и њиховим животом, њиховим нагонима, тежњама, мислима и веровањима, са њиховом вечитом потребом грађења и разарања, са неразумљивом игром међусобног привлачења и добијања. А друго, друго је свет новца, царство стицања и штедње, скровити и тихи, само мањини познати, али бескрајни предео безгласне борбе и сталног сновања у коме владају рачун и мера као два нема божанства. Нечујан и невидљив, овај други свет није ништа мањи ни мање разноврстан ни мање богат од оног првог. И он има своја сунца и сазвежђа, своја свитања и помрачења, своје успоне и падове, своје благослове и неродице; и он има велику, нејасну снагу свога унутарњег смисла, животног начела на коме све почива и око кога се све креће, а који слаб и смртан човек може само да наслути и назре. Тај тамни и наопаки свет она је сматрала лицем, а онај први начичјем.

То је свет коме целим својим бићем припада Госпођица и у коме она стварно живи. А њен живот у овом нашем свету личи умногоме на живот аскета који је одавно и потпуно нашао мистичну везу са божанством и у њ пренео тежиште свога живота, па сада се још само привремено и пролазно, јер моpa, креће овде међу нама; креће се лако и слободно и насмејано, јер за њега све што је изван његовог стварног света не заслужује друго до осмеха којим одрасли гледају дечије игре и играчке. (Андрић, 1963a: 84-85)

Као и сви они који ,живе више од своје погрешне представе о животу него од живота самог" (Андрић, 2008: 427) и Госпођица закорачује на стазу сигурне пропасти, лишена моћи реалистичког поимања како других људи, тако и себе, и претвара се у папирнати књишки лик - тип тврдице лишен сваког идентитета и сваког садржаја осим трагике.

Пример трећи: Кључни лик Андрићевог дела - лик Ћамил ефендије - такође је слика и прилика несрећног појединца, који се, као и трагични јунак његове књишке идентификације, нашао у процепу између подељених и су- 
протстављених светова, неспособан да изађе из своје задатости, да изађе из себе и оствари везу са другим човеком који би га учинио стварним и способним за живот. Борбу за живот у свету Ћамил је изгубио, изгубивши прву битку која му је одузела биће за којим је чезнуо: „Тада је тек право и потпуно могао да види оно што раније, занесен и млад, није ни слутио: шта све може да дели човека од жене коју воли, и уопште људе једне од других." (Андрић, 1963б: 64) Изгубивши тачку ослонца у свету, тачку која га је оспољавала и чинила оним што јесте, напустивши борбу за друго биће којем је стремио и желео га поред себе, Һамил се као личност расплињује, његов идентитет почиње да се урушава. Жудња за јединством и пуноћом, заокруженошћу и спајањем, преусмерена је са стварне особе из спољашњег света ка унутра, у личну фантазију са којом се, као са истоветним бићем из процепа, Ћамил поистоветио. Зато што је његов историјски близанац такође човек задатог идентитета, у којем га држи неподношљива подељеност историје, али и његова лична опредељеност да га не надиђе и превазиђе.

За разлику од свога брата, који је оличење усаглашености са реалним и постојећим, „који у сваком часу зна шта треба а шта не треба учинити, шта се може а шта не може тражити од других и од себе”, као „сушта противност његова”, Џем султан човек је „чије тежње стално иду мимо оно што треба и изнад оног што се може”. (Андрић, 1963б: 83) Како би рекао омиљени Андрићев филозоф Данац Зерен Кјеркегор, био је то човек за којег се не може рећи да је свету недорастао (незнањем или духовном инфериорношћу) већ да је, као неки „дугоноги паук”, „стварност превазилазио” (Кјеркегор, 1999: $10)$, знајући све, али одбијајући да промени оно што је сматрао суштинском одликом свог идентитета:

А за њега не постоји могућност бекства. Васколико обитавани и познати свет, подељен на два табора, турски и хришћански, нема за њега прибежишта. Јер, тамо или овде, он може бити само једно: султан. Победнички или поражен, жив или мртав. Зато је он роб за ког нема више бежања, ни у мислима ни у сновима. То је пут и нада мањих и срећнијих од њега. А он је осуђен да буде султан, заробљен овде или жив у Стамболу или мртав под земљом, али увек и само султан, и једино у том правцу би могао бити његов спас. Султан, и ништа ни за длаку мање, јер би то значило исто што и не бити, ни за длаку више, јер више од тога нема. То је ропство од ког бежања нема ни после смрти (Андрић, 1963б: 105)

Ипак, у Џемовој позицији има нечега што га суштински одваја од Ћамила, нечега што је етичко и трагичко опредељење лепе и мудре Авдагине кћери која је знала да је једини излаз из процепа који јој је живот наметнуо капија моста и река у којој ће се њен живот окончати. ${ }^{2}$ Сучељен и супротстављен фра Петру, који у проклетој авлији живота и може да преживи управо зато што га позиција слушаоца и причаоца прича чини способним

\footnotetext{
Ови случајеви показују да се управо у том процепу из кога нема излаза њихов прави идентитет и
} потврђује, и да је останак у њему и питање етичко. 
да видећи друге, види себе у светлу које реалност чини могућом, савладивом и преживљивом, ${ }^{3}$ Ћамил је у исто време и симбол човека-уметника али и болесног човека „погрешног првог корака”, окренутог не ка свету већ йрема себи - корака који је тек прва степеница ка провалији што гута сваког оног који из те стварности исклизне. Иако код читаоца изазива више симпатије и сажаљења (као према бићу високе културе, истанчане сензибилности), које овај опет дели са фра Петровом дубоком емпатијом засењеном само нелагодношћу осећаја кривице што на тај пут трагичног сурвавања невино осуђеног није могао да стане, и Ћамил је само још један у низу оних ликова који битку са животом губе пошто су изгубили реалну представу о себи, пошто су, захваљујући читавом спектру различитих опсесија, претходно прекинули контакт са реалношћу и другим људима. Иако сам појам идентитет упућује на „изједначавање”, једнакост, ${ }^{4}$ као заокружена представа о сопству, требало би означава јединственост појединца у оквирима универзалне општости, јединственост стечену и различитим врстама припадности другоме. Поистовећивање са другим, било да се ради о књишкој или историјској реконструкцији неког ко је живео у прошлости, као што то чини Ћамил, или о склоности поистовећивања са било којом идејом, верским концептом или апстракцијом којој је склон Марио Колоња из Травничке хронике, за Андрића је само доказ да свако такво створење, ма како племенито било, полако али сигурно раскида конце са стварношћу и светом у којем живи, клизећи полако у суноврат, у нестајање.

Да ли је у случају аустријског титуларног лекара живот у процепу, на граници двају светова - хришћанског и нехришћанског - претходио изградњи његовог карактера „доследне несталности” у којој је овај своје мишљење час „подешавао према мишљењу онога с ким говори”, а час „заузимао смела гледишта против свију и свакога и бранио их храбро и тврдоглаво, залажући се цео, без обзира на штету и опасност по себе" (Андрић, 1963: 241) - не знамо. Тек његова склоност поистоветити се, „извесно време са предметом проучавања, одушевити се за њега, усвојити га бар тренутно као своје једино веровање и одбацити све што је раније веровао и чиме се дотле одушевљавао" (Андрић, 1963: 240), говори читаоцима да се ради о човеку изузетног духа способног „за необичне залете” али исто тако предодређеног за извесну трагику идентитета за којег су и крајња издвојеност и крајње изједначавање подједнако кобне те да га, уместо ка развоју и изградњи, воде ка потпуном укидању. ${ }^{5}$

\footnotetext{
У Знаковима йоред йуйа Андрић примећује „да људи који не умеју да причају нису способни ни да слушају туђе причање” (Андрић, 2005: I 239)

4 Лат. identitas у значењу „истоветност”, на српском језику би га најбоље било исказивати као „Једнодушност".

5 Колоњин хировити „излазак” у свет и спашавање једног људског живота наводним „потурчењем” даје овом лику нешто од етичке супериорности саможртвовања за другог, што га на први поглед издваја из његовог аутистичног света идеја. Међутим, све оно друго што је Андрић рекао о овом грађанину „трећег света” не говори у прилог томе да је његов „испад” био последица сасвим свесне и ка бризи о другоме окренуте одлуке.
} 
Пол Остер је писац којег такође опседају пукотине стварности: црне рупе психолошког времена и простора које модерног човека физички држе у једној стварности, али га чине становником паралелних светова. Посебно је то видљиво у чувеној Њујорщикој йрилог̄uји (The New York Trilogy, 1987), роману-триптиху, ${ }^{6}$ који се бави истраживањем идентитета усамљеног јунака житеља модерног Вавилона. Писац дубоке свести о нестабилности језика (што је и једини медујум, осим физичког контакта, који нас може повезати са другим, и на којег је и сам писац, као и сваки други писац у историји, осуђен), Остер, као у неком постмодерном золијанском експерименталном роману, у свом фикционалном првенцу истражује које су то све тачке ослонца што их јунак треба да изгуби да би се „истопио”, расплинуо, нестао као јединствено и аутентично људско биће колико-толико стабилног идентитета.

Остер је писац који тематизује живот у граду од стакла - граду који појединцу лако измиче и одузима свако чврсто упориште. Квин испрва губи породицу, а потом, постепено и идентитет писца детективског романа који пише под псеудонимом, поистовећујући се са властитим јунаком, и живећи животом усамљеника коме је једини смисао да открива тајне једног жанровски задатог дискурса, да би, а захваљујући истом таквом тајновитом задатку што му га је наметнула игра судбине, досегао крајње границе изолације и одвоједности. Без дома и окриља, живећи у процепу зграда, без крова над главом, незаштићен грађевинама које човека деле од природе и пружају му дом, склониште, окриље, Квин у фантазмагоричној завршници првог романа у триптиху (Град од стйкла) бива сведен на језик којим пише своје последње дело. Иако осећа готово рајску испуњеност у тој ултимативној секвенци свог живота (који се може тумачити као живот у паралелној не-реалности), његов крај, али и крај романа мора да се отелотвори у самоукидању. Јер могућност живота у предметном и телесном свету који нас ограничава (крај црвене свеске) подразумева бесконачну борбу - излажења из себе, надилажења и надрастања задатости које нам намећу тело и свет реалности. Када тај инстинкт борбе и жеља за поновним успостављањем нарушене равнотеже исхлапе, живот на овој земљи се завршава.

Њујоршки бескућници свакако су за Остера били важан део његовог уметничког посматрачког експеримента. Посматрајући их, он види

Trupine živog očajanja, odevene u rite, natečenih i krvavih lica, oni se vuku ulicama kao u lancima. Oni koji su usnuli u ulazima zgrada, oni koji se kao ludi teturaju između vozila na ulici, ili padaju u nesvest na pločnicima - čini se da ih

\footnotetext{
Наслови сваког од три дела Њујорщике тирилог̄ије упућују на три начина или пута који воде до пражњења, губљења идентитета: „град од стакла” као симбол непоузданости и крхкости спољашњих ослонаца као основних координата идентитета, „духови” - као вишезначан симбол расплинуте телесности, немогућег, недефинисаног односа јединке и стварности и „закључана соба” - као одсуства врата које воде у спољашњи свет.
} 
ima na sve strane, svaki put kada ih čovek potraži. Neki će umreti od gladi, neki od lošeg života, a neki će biti pretučeni ili spaljeni ili mučeni.

$\mathrm{Na}$ svaku dušu izgubljenu u tom paklu, postoji nekoliko drugih koje su zarobljene ludilom - nesposobnih da izađu u svet koji stoji na pragu njihovih tela. Premda se čini da su tu, ne mogu se smatrati prisutnim... (Oster, 2008: 99)

За Остера, велики град попут Њујорка, најбоље је место да се човек изгуби „ne samo u gradu već i u sebi” (Oster, 2008: 9). Усамљеност, кидање веза са људима из заједнице којој појединац припада, послужила је овом поштоваоцу Поа (Edgar Alan Poe) и Topoa (Henry David Thoreau), у првом роману њујоршког триптиха, за тематизацију још једног карактеристично постмодерног питања - питања нестабилности и непоузданости језика као пута ка Другом. У бизарној причи о оцу који изолује властито дете како би открио „језик невиности”, божији језик којем су прародитељи човечанства говорили у рају пре пада, Остер даје читав каталог сличних историјских примера, од приче „,ozloglašeno nepouzdanog hroničara” Херодота, преко архетипског књижевног усамљеника Робинзона Крусоа, до загонетних и никад нерешених случајева као што је историја Каспара Хаузера или Питера из Хановера.

Jedini Adamov zadatak u vrtu bio je da izmisli jezik, da svakom biću i svakoj stvari nadene ime. U tom stanju nevinosti, jezik je pogađao pravo u suštinu stvari. Te reči nisu samo jednostavno nakačene na predmete koje je video, one su otkrivale njihovu suštinu, doslovno ih oživljavale. Stvar i njeno ime bili su međusobno zamenjivi. Posle pada, to nije više važilo. Imena su odvojena od stvari, reči su se pretvorile u zbirku arbitrarnih znakova, jezik je otrgnut od boga. Piča o raju stoga ne samo da beleži čovekov pad već i pad jezika. (Oster, 2008: 43)

Само постмодерно стање човеково које је резултат спознаје о томе да је основно средство којем је посегнуо ка другоме, ка објекту, ка свету - да би га истражио и открио тајну свог постојања у њему - произвољно и непоуздано, осећање које га је после позитивистичког оптимистичког замаха и самопоуздања, вере у напредак, поново учинило малим, ништавним и без ослонца, представља, дакле, једно од кључних и опсесивних тема једног од најпознатијих америчких писаца миленијумског прелома.

Да је Иво Андрић и сам итекако био свестан непоузданости човековог говора, вишесмислености која са једне стране чини богатство и лепоту уметничке писане речи, али са друге може да доведе у питање и сам живот када се та уметност, или било која идеосинкразијска експресија тумачи у тоталитарним друштвима и системима као субверзивна и опасна по постојање самог тог система, види се из прича у којима је, верујемо тематизовано и његово поменуто лично младалачко искуство када је почетком Првог светског рата због једне песме завршио у Мариборском затвору. Али, експли-

\footnotetext{
Аустријске власти сматрали су Андрића сумњивим због чланства у југословенски оријентисаним организацијама у време када је био гимназијалац у Сарајеву, али и због једне песме објављене 1914. године у Черинином Вихору под насловом „Прва прољетња песма” чији лајтмотивски стих гласи „Кад ли ће доћи краљеве војске?”
} 
цитно, Андрић је о овоме проговорио још 1937. године у једној својој прози под насловом „Ликови”:

У муњевитом скраћењу видим историју људске тежње за изразом. Видим, невино мирно царство првих ликова, кад је за сваки лик била потребна нарочита воља и нов напор, кад је сваки од остварених ликова казивао само оно што јесте и што жели да буде, неокаљан и невезан безбројним и варљивим асоцијацијама које су доцније, истина, обогатиле људско осећање и мишљење, али су их зато одвели на мучна и безизлазна беспућа. И видим одмах и почетно лукавство човеково - лукавство чија ће он сам бити прва и главна жртва - његову тежњу да ликове зароби, потчини и упрости, као што је полако заробљавао друге снаге и појаве у природи, и да једним ограниченим и утврђеним бројем ликова, којима је лако владати и просто руковати, изражава све остале појаве и све своје мисли, жеље и потребе у вези са њима. Кратко: да ликови не показују, као до тада, само оно што су и што они сами значе, него да казују.

То је раскрсница од које почиње наше лутање и мука духа. И ја мислим да у овим наглим и дубоким реакцијама, које се с времена на време јављају у нама према писаној речи, живи, у основи, дубока људска тежња за изгубљеним рајем слободног гледања и чистих безимених ликова. Смисао и целисходност одавно су заробили те ликове и потчинили их нашој вољи и одвели, заједно са њима, на ове путеве који су дужи и тежи него што су наша снага и наше стрпљење.

Ово је такав тренутак. Гледајући са ових обасјаних степеница, чини ми се да постоји само она реч која је „постала тело”, јер су једино за њу сведочили, удружени, људски напор и логика материје, док ми неоваплоћена реч изгледа само празан и варљив звук који још није успео да се отме оковима хаоса што нас окружује. (Андрић 1963: 102-3)

Може ли се доћи до те „оваплоћене” речи, питање је које је једно од суштинских питања како за Иву Андрића, тако и за Пола Остера. Андрићева „филозофија ћутања” која га је приближила италијанском историчару и државнику Франческу Гвичардинију (Francesco Guicciardini (1483-1540)), аутору моралистичких фрагмената, а која се у његовом делу може тумачити и као врста егзистенцијалног страха (ћутање као одбрана од живота) најочитијег у можда најлепшој његовој приповеци „Мост на Жепи”, на другом свом полу претвара се у естетички идеал. Мерити сваку реч, отклањати сувишне, редундантне елементе језика који не преносе било какву информацију - нити појмовну, нити естетску, ${ }^{8}$ морало је свакако водити и оном

\footnotetext{
У једном запису из Знакова йоред ӣȳ̄a у којем се говори о расцепу између мисли и језика, Андрић размишља врло слично Остеру: „Између човекових мисли и његових речи којима те мисли жели да изрази постоји понајчешће очигледан јаз. За своје прве и основне мисли он је тешко и споро налазио изразе који су из почетка морали бити једноставни, рудиментарни, али, с временом, је број тих израза постајао све богатији а људи сами све сложенији, док се број мисли није повећавао у истом ритму. За сваку мисао (и помисао) човек је налазио све изразитије и све прикладније речи,
} 
„сажимању”, „стезању” ткања Гојине тетке Анунцијате из Фуенте де Тодоса. Приповедање и прича су, и по Андрићу и по Остеру, пут то рајске невиности језика која би, пошто је разумевање поново сведено на једно значење, на извесност и стабилност комуникације са другим, поново ујединила људе у предвавилонску заједницу. Са друге стране, то би био језик који би човеку омогућио да говори о „суштини ствари”.

Очигледно је, међутим, такође, да су и Андрић и Остер свесни чињенице колико је такав зацртан идеал тешко домашив. Нетачно би било говорити да је у размишљањима ових писаца могуће уочити и огромна одступања и разлике. Док је телесност људска код српског писца редовно представљена као део анималне сфере коју треба превладати, Остер у човековој чулности види могућност налажења оне тајне постојања која измиче рационално-филозофским увидима у стварност. Па ипак, чак и када су разлике извесне и очигледне, лако је уочити да су оба аутора постављала себи једно од најбитнијих питања везаних за идентитет, а то је питање континуитета једнодушности у једној особи, односно истраживање тзв. вишеструких живота, мултипликованих идентитета омогућених метаморфозама појединца у току једне људске егзистенције.

Као писцу Босне и Балкана Андрића пре свега занимају личности конвертита - особа који су рођене као хришћани, али су, стицајем различитих околности, променили веру, поставши нешто друго од оног што су били. (И Андрићева лична одлука да се, определивши се за традицију вуковску и његошевску, приволи српској нацији и себе одреди као српског писца, може се посматрати као важан чинилац тог интересовања.) Нарочито су занимљиви примери Омерпаше Латаса, турског војсковође - чија се додуше недовршена прича налази у средишту истоименог постхумно објављеног романа, али и кроки-портрет једне такође историјске личности (коју помиње и Казанова у својим мемоарима) - чувеног Бонвалпаше из једне од прича постхумно објављене Андрићеве збирке Кућа на осами (1976). Остерова опсесивна тема која се понавља у више његових романа - јесте прича о људима који су нестајали, уверивши тим нестанком своје најближе у своју смрт, док су, заправо, под другим именом и идентитетом настављали да живе новим животом - посматрајући из прикрајка живот, тј. људе, породицу, које су својом или туђом вољом напустили. Не улазећи у дубља и опширнија тумачења ових идентитетских „мутација” код ових писаца (као и етичка питања које оне за собом повлаче) јер би то свакако открило и различите полазишта и елаборације овог проблема, мислим да треба истаћи оно што је овде заједничко и универзално: а то је да идентитет није ствар рођења, не нешто што добијамо на поклон када закорачимо у овај свет (као име са којем Остер

али и за сваки недостатак мисли, или њену немоћ или нејасност, човек је опет налазио речи. Тако се у живом ткању људских језика, с временом, стварао све већи број јалових, нездравих ћелија које су притискивале оне здраве и живе, изазване потребом и оплођене мишљу. Због тога у језицима свих народа, нарочито јужних, постоје толике речи које немају мисаоне подлоге и циркулишу као лажне паре помешане с правима.” (Андрић, 2005: I 225) 
воли да се поиграва указујући на његову суштинску арбтрарност) већ да га градимо делујући у стварности у којој смо се затекли. И у случају промене идентитета преласком из једне заједнице у другу, из једне улоге у другу, аутентичност „новог” човека не мора бити нарушена. Напротив, она се и овде мери природом интеракције са другим члановима заједнице или актерима света у којем се „измењени” појединац нашао.

Ако наставимо са поређењем, и тражењем сличности и разлика тема и мотива које проналазимо код ових писаца, оно што ће као прво и упечатљиво пасти у очи јесте чињеница да је једна од главних тема Американчевих фикционалних али и нефикционалних дела - тема очинства (као још једна варијација идентитетске приче). Изгледа готово невероватно колико је Андрић, као писац који је поринуо тако дубоко у просторе несвесног, откривајући нагонску сферу ероса и деструкције, био потпуно „слеп” за стара питања очева и деце које је морао да среће и у литератури - не само код Руса већ и код његовом вршњаку Црњанском тако блиских скандинавских драматичара Ибзена и Стриндберга. Да ли нам ово ћутање говори да је очево одсуство било искуство које је Андрића много више одредило него што смо били склони да наслутимо?

О својој усамљености, нелагодности и тегобности живљења писао је Иво Андрић у својим Знаковима йоред йуйа. ${ }^{9}$ Савременици га памте као пословично затвореног човека који је нерадо говорио о себи и свом стваралаштву. Жеља да се, изузевши све лично из својих прича, створи дело које ће изгледати као анонимни рукопис извађен из боце ношене таласима океана, као народни певач заборављеног имена и личног живота, свакако је била усмерена ка ослобађању оног тегобног притиска стварности. Жалио је што псеудонимом није одагнао све конотације свог имена, као непотребне (али и претеће) сенке под којим је то дело настајало.

Да је текст начин да се писац суочи са самим собом, да је огледало у којем писац види и сазнаје себе, знали су то и Андрић и Остер. Има ли писац уопште свој живот, или се у писању поистовећује са својим јунацима? „Често се дању и ноћу (нарочито ноћу!) питам да ли ја то само пишем о неком који пати, или заиста гледам и видим оног који пати, или то ја сам и патим и описујем своју рођену патњу.” (Андрић 2005: I 201) Да је и само писање и читање (у суштини чинови тако усамљенички) опасан посао који лако може да нас у тој усамљености повуче у вир „друге стварности”, видели смо већ на Ћамиловом примеру. Отуда нас, Андрићево инсистирање на одржавању реалистичке и објективистичке дистианце поново враћа са домена естетике на питање егзистенцијалног страха. Од писања, међутим, ни један ни други писац не одустају, зато што су, са друге стране, обојица дубоко свесни да је управо йрийоведање она магична спона која држи на окупу и приповедача

\footnotetext{
„Чини ми се кад би људи знали колико је за мене напор био живети, опростили би ми лакше све зло што сам починио и све добро што сам пропустио да учиним, и још би им остало мало осећања да ме пожале.” (Андрић, 2005: I 21)
} 
и читаоца (слушаоца), помажући им да издрже и носе свој идентитет. ${ }^{10}$ Знакови поред пута које нам даје прича, који нам помажу „да се нађемо и снађемо", нису ништа друго до оријентири и упоришта који нас држе у стварности, не допуштајући да исклизнемо из ње.

Иако на први поглед тако поетички удаљен од Андрића, и Пол Остер је од самог почетка свестан те готово магичне моћи приче: попут оног Андрићевог детета у мраку које шапуће не би ли одагнало страх, већ у Ойкривању самоће он зна да приповедајући свој живот решава и своје личне дисбаланce, нестабилности, да се отвара ка Другоме. Још у првом свом делу аутобиографског садржаја овако је протумачио древну причу о Шехерезади коју је као параболу поменуо и Иво Андрић у свом говору приликом примања Нобелове награде 1962. године. Према Остеру, свака опсесија окива човека самоћом. „On ne vidi ništa osim vlastitih misli. Priča, međutim, pošto nije logička rasprava, raskida te okove. Jer ona pretpostavlja postojanje drugih i omogućava slušaocu da dođe u dodir s njima - makar samo u mislima." (Oster, 2000: 151)

Ове Остерове речи откривају нам, можда, колико су прича и причање били суштински важни за одржавање Андрићевог идентитета - као осећања целовитости које му омогућава, упркос свим страховима, да плива и постоји. Иако је и сам, видимо то из његових забелешки, осећао тежину своје усамљености, ${ }^{11}$ издвојености и посебности као човека и уметника, Иво Андрић је, уместо да се тој издвојености и усамљености преда, одолео амбису и химерама „другог света” које би га одвукле од стварности. Зато што се од стварности није бранио, и што је у некој инстинктивној борби самоодржања знао да своју судбину уметник треба да подели са животом угрожене заједнице - што је сасвим очигледно по одлукама које је донео по окончању берлинске дипломатске каријере и останком у окупираном Београду. Посезање за Другим, жеља да се живи као део колектива, упркос свим силама које су га гонили да остане у себи, приметне су тежње у Андрићевој биографији. Можемо претпоставити и да се, приповедајући, он заправо борио да допре до другог човека, али и да преживи у реалном свету, онако како што је то чинила Шехерезада. Тако се може рећи и да је само таква реч, усмерена ка другоме, као путоказ и знак, она андрићевска реч која је постала „тело” и која се није изгубила у бескрајностима идеосинкразија - гутачима реалности и другости као главних ослонаца идентитета.

О томе, управо, чини ми се говори и једна друга опаска Пола Остера да „ako se detetu zabrani ulazak u imaginarno, nikada neće umeti da se nosi sa

10 „Бити човек, рођен без свог знања и без своје воље, бачен у океан постојања. Морати пливати. Постојати. Носити идентитет, Издржати атмосферски притисак свега око себе, све сударе и непредвидљиве и непредвиђене поступке своје и туђе, који понајчешће нису по мери наших снага. А поврх свега, треба још издржати и своју мисао о свему томе. Укратко: бити човек.” Том човеку, каже Андрић у својој беседи пред Нобеловим комитетом, прича говори „нешто више него што ми у својој слабости, можемо да сазнамо и схватимо."

11 „Ја бих могао да узмем за девизу име једне канађанске лађе: I'm alone (Ја сам сам). Али ја сам и без девизе.” (Андрић, 2005 I: 256) 
stvarnošću” зато што је његова потреба за причама базична „koliko i potreba za hranom, i manifestuje se na isti način kao i glad" (Oster, 2000: 154) која нам открива оно унутрашње дете у Андрићу, али и у сваком човеку, за кога је прича један од кључних ослонаца у свету у којем треба да испуни своје сопство и изгради свој идентитет. У том смислу посматрано, вера Остера и Андрића у причу као мост, или сабатовским језиком речено, тунел, који, упркос свим несавршеностима језика, у крајњем исходу води од човека до човека, говори о томе да постоји безвремена заједница приповедача и слушалаца (читалаца), која надилази све поделе на раздобља и стилске правце. Заједница која људска бића спашава од сваке, било модерне, било постмодерне усамљености.

\section{ЛИТЕРАТУРА}

Андрић, И. (1963а). Госпођица. Београд: Просвета и др.

Андрић, И. (1963б). Проклета авлија. Београд: Просвета и др.

Андрић, И. (1963в). Стазе, лица, предели. Београд: Просвета и др.

Андрић, И. (1963г). Травничка хроника. Београд: Просвета и др.

Андрић, И. (2003). Писма Војимиру Дурбешићу. Нови Сад: Матица српска

Андрић, И. (2005). Знакови поред пута I и II. Београд: Политика, Народна књига.

Андрић И. (2008). Сабране приповетке. Београд. Завод за издавање уџбеника.

Кјеркегор, 3. (1999). Дневник заводника (прев. Милан Табаковић). Нови Сад: Светови.

Oster, P. (2000). Otkrivanje samoće (prev. Ivana Đurić Paunović). Beograd: Geopoetika

Oster, P. (2008). Njujorška trilogija (5. izd. prev. Ivana Đurić Paunović, Zoran Paunović,

Svetlana Spaić). Beograd: Geopoetika.

Павловић, М. (2010). Поетика жртвеног обреда. Београд: Просвета.

Горана Раичевић

\section{ИСКЛИЗНУЋЕ ИЗ СТВАРНОСТИ: ИДЕНТИТЕТ КОД ИВЕ АНДРИЋА И ПОЛА ОСТЕРА}

\section{РЕЗИМЕ}

Рад представља компаративну анализу проблематике идентитета код Иве Андрића и Пола Остера. Закључује се да је ова тема код оба писца неодвојива од поетичких питања, при чему се приповедање и прича откривају као егзистенцијалног сналажења у реалности, односно као чувари успешно успостављеног идентитета. 
Gorana Raičević

\section{SLIPPING OUT OF TOUCH WITH REALITY: IDENTITY IN IVO ANDRIĆ AND PAUL AUSTER}

\section{SUMMARY}

The essay offers a comparative analysis concerning the problem of identity in the work of Ivo Andric and Paul Auster. It has been found that in both cases this issue is being inseparable from theoretical and meta-fictional questions while narration and narrative according to both writers as guardians of stable identity represent keys to coping with reality.

Key words: Ivo Andrić (1892-1975), Paul Auster (1947), identity, language, reality 